\title{
WALKING OUR TALK?
}

\author{
JAMES A. F. STONER \\ Gabelli School of Business \\ Fordham University, New York, New York, U.S.A. \\ stoner@fordham.edu
}

In the very first issue of this journal, Seattle University professor William L. Weis gently inquired about the extent to which we were actually walking our talking about sustainability in his own and other Jesuit business schools (Weis, 2013). Or perhaps you might say that he "called us out" on the extent to which we were not doing so. The nature of his inquiry and the questions he asks are universal, applicable to all business schools and universities around the world, yet the challenges to action he presents are especially appropriate for Jesuit business schools (and universities) because of their faith-based values and explicit mission statements.

Seven years later, Marinilka Barros Kimbro, Rubina Mahsud, and Davit Adut, also from the Albers School of Business and Economics at Seattle University, continue that type of inquiry and take it to a new level by asking Jesuit universities if they are "putting their money where their mouths are" when it comes to investing endowment funds. In the first of two articles in this current issue, they explore the extent to which Jesuit universities based in the United States are supporting the fossil fuel industries that contribute so much to the climate change and global warming that is rapidly destroying the capacity of the planet to support our own and other species. Or, more precisely, they explore the extent to which those institutions have divested from fossil fuels through the removal of fossil fuel assets from their endowment portfolios.

Kimbro, Mahsud, and Adut then move on in the next article to explore the reasons that are frequently offered both for and against divestment from fossil fuel securities. They find the reasons supporting divestment to be stronger, on balance, than the reasons in favor of maintaining such investments, and come to the conclusion that all universities, both Jesuit and otherwise, should divest from such securities not only for definite moral and ethical reasons but also out of financial concerns. They argue that divesting from an industry whose future is more and more 
in doubt may be more prudent and wise than continuing to hold on to its assets. The financial and moral fiduciary responsibilities of university endowment investment officers, therefore, can be aligned when calling for divestment now.

These articles by Weis, Kimbro, Mahsud, and Adut, along with the four others in this issue, remind us that we will need to discover answers to five major questions and take action on them if we are to find some way to meet the greatest intellectual and moral challenge our species has ever faced.

1. How can we deal very, very soon with climate change, global warming, and their immediate related impacts (discovery and action)?

2. What kind of people do we need to become to flourish on this planet without destroying it, and hopefully even to heal it (discovery)?

3. How can we become those kinds of people-all of us-very, very quickly and with dignity, respect, and care for unique circumstances and ways of being (action)?

4. What kinds of planet-protecting production, distribution, and consumption systems will provide the goods and services needed so we all can lead flourishing lives (discovery)?

5. How can we bring those systems into being (action)?

Discovery and action for the common good-these have always comprised the fundamental mission of business education. That mission has long been lost, however, in the simplistic and wrong-headed definition of the business firm's first and foremost (and ultimately "only") purpose as being to enrich shareholders, executives, and speculative traders. It is a definition justified, in part, by the assertions that the unrestrained pursuit of selfish ends guarantees the greatest level of the common good and that we are empty shells both morally and emotionally, seeking only ever-growing and endless consumption to achieve what we perceive to be true bliss and our hearts' desires. Such perspectives have been bolstered by an unquestioning insistence that acceptance of the neoliberal narrative alone will protect us from swarming lemming-like on the road to serfdom, something inevitable 
in societies where any aspect of the popular will is expressed through any form of governmental action.

Framing these five questions in terms of discovery and action may therefore suggest opportunities that the world's business schools have to steer a course out of the "dangerous shoals and roaring breakers" (Stobaugh, 2012) ${ }^{1}$ of the world, shoals and breakers which we are finally realizing we have been blithely drifting into for more than a half century. These institutions can play a significant role both in understanding the actions needed to move away from our dependence on fossil fuels and in bringing about that shift very rapidly. They can take the lead in grappling with all five of the questions/challenges listed above and in finding alternatives to the dominant neoliberal paradigm, particularly as suggested in this issue's invited essay from Fr. Garanzini. These challenges are tailor-made for the leadership and contribution of business schools, institutions that have the missions, intellectual and financial resources (yes, even in this period of coronavirus-induced turmoil and uncertainty), and even self-interest to discover and bring into being the answers and actions that we need.

There are, of course, many issues and tragedies connected to social justice, global poverty, well-being, human dignity, morality, ethics, and care that cry out for our attention every day. Some are closely connected with these five "problems" or "challenges"; others may not be. When we have dealt with the immediate problem of the current COVID-19 global pandemic, prepared (hopefully) for the next one, whatever it is, and "solved" the pressing problem of climate change in a way that enables our species to remain on this planet and flourish, we will still need to deal with a myriad of other concerns: HIV/AIDS, starvation, seemingly endless types of diseases, the population bomb that exploded long ago, species extinction, and so on. Yet we will not be here to deal with these other issues if we do not "solve" the climate change problem. In that sense, dealing with climate change and global warming is our "first priority."

There is no HIV/AIDS, or starvation, or social injustice on a dead planet. 
So, for business schools, "Now What?" The remaining articles in this issue continue the attempts to address pieces of that "now what" question which Weis, Kimbro, Mahud, and Adut have themselves addressed.

In the invited essay that appears first in this issue, Fr. Michael Garanzini reports on an inquiry into the purpose and role of Jesuit business education that may go far beyond what is taught and researched in business schools that are "just" Jesuit or even "just" Catholic. That inquiry is part of a growing worldwide recognition that American and, increasingly enough, global business education have been, for at least a half century, active servants to and enablers of the "business as usual" practices that have been destroying the capacity of the planet to support our own and other species. As Laszlo, Sroufe, and Waddock (2017) note, business education has been, to a very large extent and with a few notable and valuable exceptions, both the victim and the servant of the neoliberal narrative that has inculcated in us the businessas-usual mindsets, values, tools, and weltanschauung that have played such a major role in getting us into the global mess we are now in.

Thus, while what Fr. Garanzini reports is led from and couched in terms of Jesuit and Roman Catholic values and missions, it is much more than a call for an inspired paradigm of Jesuit business education addressed to Jesuit and Roman Catholic institutions. It will be heard appropriately by many others as much more than a mere attempt to "build the Jesuit brand" or improve the position of Jesuit business schools in the competition for students and resources. It will be heard by many as just what it is intended to be-an invitation in the spirit of Laudato Si' for all business educators and leaders-faculty, students, alumni, and supporters-to engage in their own dialogues about what business education can become for the common good. It is, very importantly, an invitation extended by example to inspire business schools to conduct their own dialogues about the actions we need to take to meet the challenges we face.

In "Assessing sustainability initiatives in higher education institutions," Justin Edric G. Yturzaeta of Ateneo de Manila University focuses directly on the task of ensuring that education in business schools and beyond is really geared toward a sustainable, flourishing, and regenerating world. He observes that each higher education institution (HEI) plays a unique role in the academic landscape given its special context, namely, its geographical location, resources, target market, and areas 
of specialization. Nevertheless, all HEIs face the challenge of making sustainable development central not only in their research and curriculum but also in their operations as organizations.

Yturzaeta describes how a rapid sustainability assessment tool has been developed for HEIs to aid them in evaluating and managing their sustainability initiatives. The tool also acts as a framework that can help HEIs maximize the sustainable value they create in their own contexts for today and tomorrow, inside and outside their organization, and in the environmental, social, governance, and academic dimensions. In the spirit, then, of the oft-quoted business maxim "what gets measured, gets done," Yturzaeta's study offers a means to help business schools and other institutions get some of the work-of global sustainability, flourishing, and regeneration-done.

In "Creating sustainable business: How does it happen? An exploration of motivators \& facilitators in three organizational settings in the U.S.," Robin T. Byerly of Appalachian State University addresses the fourth and fifth questions for business education outlined above, particularly with regard to how we can bring into being the types of productive organizations that we need. She begins by acknowledging the fundamental premise that efforts to manage for sustainability must extend to all types of organizations and institutions, be they small, large, domestic, or global. She notes that while many businesses already engage in sustainability initiatives, some more honestly and expansively than others, many fail either to be motivated or to move effectively toward sustainability in their business models. Interface Carpet and Patagonia, to name but a few, are notable examples of such firms that have fully embraced the dedication to pursue sustainability in all aspects of operation. It is increasingly imperative, however, that more do so to the fullest extent possible.

Byerly asks, therefore, how we can better understand the ways by which various institutions actually create sustainability models, noting that theory provides clues regarding both motivating factors and circumstances that might prove inhibiting for companies attempting to move toward greater sustainability. Her article presents three organizational cases of companies that are similar in their stated sustainability purpose, quest, and uniqueness, and yet different in size, industry, and environment. While these differences are meaningful as can be seen from the triangulated evidence she presents, lessons can be learned from many similarities that emerge in spite of 
the differences. Indeed, there is still so much to learn by actually exploring the very institutions that are actively engaged in these efforts and digging deeply into the motivating and facilitating realities that they represent.

In "Start-up or scale-up? An approach through economic impact," Joaquín Garcia-Tapial and Manuel Alejandro Cardenete of Universidad Loyola Andalucia explore the very important issue of scalability for sustainability initiatives and organizations. They distinguish between start-up organizations as institutions per se and those that grow rapidly, and observe that while entrepreneurial spirit has traditionally been considered one of the main catalysts of the economy (and therefore of sustainable development as well), it was not until several years ago that public authorities in various parts of the world launched planned and organized efforts to support entrepreneurial initiatives.

The effectiveness of these investments, however, which run to millions of euros annually, is rarely considered in relation to the impact that such entrepreneurial activity has on the economy. Nevertheless, public authorities have increasingly focused in recent months on so-called scale-ups, i.e., start-ups that have experienced growth of over $20 \%$ for at least three consecutive years. The general belief, despite the fact that only a few studies on this phenomenon have been made, is that these companies have a considerable impact on the economy especially in terms of employment.

According to Garcia-Tapial and Cardenete, we must ask ourselves if we should either continue dedicating scarce public resources to the generation of new companies (start-ups) or redirect them toward the promotion of scale-ups. The main objective of their work is to explore and examine whether or not authorities should shift public resources from supporting start-ups to fostering scale-ups based on their economic impact. They study the economic impact of entrepreneurial activity (start-ups) and of a particular type of high-growth company which public authorities are currently focusing on (scale-ups) and compare the impacts of both to draw conclusions. The paper focuses on Andalusia, one of the regions with the lowest levels of development in the European Union.

Now, what else? 


\section{CONTINUING THE EXPLORATION OF FOSSIL FUEL DIVESTMENT IN THE SPIRIT OF LAUDATO SI'}

The authors in this issue are clearly passionate about the actions they would like us to take. Their work calls for us to engage in the kinds of dialogue Pope Francis invites us-and the entire world community-to enter into as we grapple with the great sustainability and social justice issues and challenges that he and the many expert advisors and institutions that supported his research and writing identify in Laudato Si' (Francis, 2015). True dialogues, in the spirit and practice of humble inquiry that Ed Schein (2013) describes so gracefully, may be powerful yet gentle ways of creating the commitments we need to make, commitments that are necessary for us to carry out the hard work that we must all do.

In the spirit of such dialogues, then, we are suggesting that a virtual conference be held on Thursday and Friday, June 10 and 11, 2021, approximately a month before the combined $26^{\text {th }}$ Annual World Forum of the International Association of Jesuit Business Schools and 22 ${ }^{\text {nd }}$ Annual Meeting of the Colleagues in Jesuit Business Education at ITESO Universidad in Tlaquepaque, Jalisco, Mexico, and that the financial officers most responsible for investing the endowments of each of the 27 U.S.-based Jesuit universities be invited. While the exact details of the conference will surely evolve over time, our preliminary suggestion is to have the sessions meet from noon to 7 P.M. ET (9 A.M. to 4 P.M. PT) over the two days mentioned, with coffee and lunch breaks scheduled throughout. Each of the 27 Jesuit university officers would also be invited to give a very short (e. g., five minutes or so) introductory summary of where they currently stand on the question of divesting from fossil fuel company securities, what plans they have going forward in this domain, and what might be most helpful to them as they consider the question of whether or not to divest from fossil fuel firms. For some who have already divested, they may of course report on the reasoning that led them to divest, and how they went about doing so.

Most of the virtual conference time would be devoted to open dialogue in the spirit of Laudato $\mathrm{Si}^{\prime}$, held in the classic form-nonjudgmental and with open sharing-and in accordance with the guidelines for dialogue presented by Walter Isaacs (1999) and others. The suggested design for the conference would not include formal commitments or understandings_-rather than position papers before the meetings or end of conference communiqué, there would only be shared thoughts, questions, and perhaps dreams and hopes. The conversations in the conference 
could be made publicly available as they occur, and the sessions could be archived for future access by any interested party.

One of the lessons learned from the COVID-19 tragedies that were in full sway while this editorial was being completed is that we can conduct such a virtual conference at essentially no cost using currently available technologies, and that attending it should involve no "carbon guilt" because no one has to travel to a common conference site. The Internet will bring us together with just a few clicks and with no burden on university budgets. For those who may be interested, the people responsible for making the conference happen can be contacted directly at kimbrom@seattleu.edu and stoner@globalmovement.net.

\section{REFERENCES}

Francis. 2015. Laudato si': On care for our common home. Vatican City: Libreria Editrice Vaticana.

Isaacs, W. 1999. Dialogue and the art of thinking together: A pioneering approach to communicating in business and in life. New York: Currency/Doubleday.

Laszlo, C., Sroufe, R., \& Waddock, S. 2017. Torn between two paradigms: A struggle for the soul of business schools. AI Practitioner, 19(2): 108-119.

Philbrick, N. 2007. Mayflower: Voyage, community, war. New York: Penguin

Schein, E. H. 2013. Humble inquiry: The gentle art of asking instead of telling. San Francisco: Berrett-Koehler.

Stobaugh, J. P. 2012. World literature: Cultural influences of early to contemporary voices. Green Forest, AR: New Leaf Publishing Group.

Weis, W. L. 2013. Hypocrisy at the lectern: Do our personal lifestyle choices reflect our spoken commitment to global sustainability? Journal of Management for Global Sustainability, 1(1): 29-45. 